\title{
The state of the church in a postcolonial era from Newbigin's perspective: Challenges and opportunities for mission
}

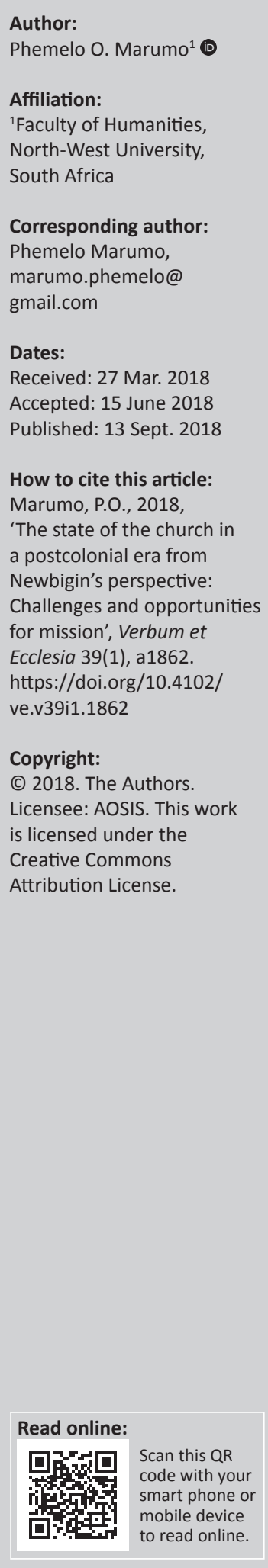

As the Christian church engaged in the so-called foreign mission, an unfortunate perception ensued that mission was of service to the colonial aspirations of the sending countries. Subsequently, labour missionaries came under suspicion as they were regarded as oppressors who robbed local communities of their culture and the way of thinking. It is in this regard that Newbigin pondered the question whether the West could be converted from ignorance and religious imperialism that exploited the local population. This gave rise to the thinking that related missiology and ecclesiology to a missional church which is Trinitarian in nature and based on missio Dei (God's plan). In this research, it is argued that mission will always be a suspect of colonial and imperialist motives that cannot contribute to the society in which it works unless the mission is conducted through a missional church which is embedded in missio Dei as presented by Newbigin. In order to address this, the research initially highlights how the mission was conducted from a missiology that was not embedded in missio Dei and how this has adversely affected the spreading of the Christian message and undermined the transformation of society. Secondly, the research shows that lack of contextualisation and not taking cognisance of the culture and the worldview of the colonised has greatly affected the mission in the postcolonial era. And thirdly, the research indicates how a missional church as advocated by Newbigin could contribute towards an effective missiological agenda that could bring unity and glorification to God in the postcolonial era.

Intradisciplinary and/or interdisciplinary implications: This article focuses on how the mission was conducted, not taking cognisance of the worldview of those it preached to. This is the philosophical implication. The other issue is that contextualisation was not taken into consideration which means the socio-cultural issues were not addressed. This article brings forth that if the blending of both philosophy and social science could be infused in missiology, then missiological attributes like koinonia and evangelism would serve as an appropriate vehicle to transport missio Dei.

\section{Introduction}

Lyall and Newbigin (1962:21) are sceptical about how the mission was conducted by the West. In his conversation with Leslie Lyall in 'The church local and universal', Newbigin argues that the West ignored the context in which missions were done, especially with regard to the ways in which the hearers' worldview was marginalised. He contends that this ignorance has led to the West seeing the congregation as one entity and the large family of origin as another. The separation of the two brought serious distortions of the message because the congregation is part of the large family. He further argues that in order for the message or the Gospel to be well understood, the Christendom mentality should be ignored and the relationship of both the congregation and the large families should be taken into consideration. He argues as follows (Lyall \& Newbigin 1962):

The Gospel does not come to the new congregation disembodied. Inevitably the missionary hands it on as he has received it and understands it. To him, it seems all in one piece. Thence it will be appropriate to distinguish between the word of God and the tradition of men. (p. 21)

This illustrated that the context of the people is critical for them to receive the Gospel as the focus of the mission.

Secondly, Newbigin (1961:22) argued that Christendom brought with itself the so-called civilisation that led to the birth of a secular setting. Civilisation ushered in technology, science and mathematics which were considered the cornerstones of knowledge (epistemology). That meant 
if one needed to know the Gospel, one had to rely on these elements of epistemology. The Gospel became secularised. The elements of this epistemological foundation were foreign to the local congregation and were not part of their worldview. This confusion complicated the way the locals received and accepted the Gospel essentially because the missionaries did not bother to bring the locals on board in both the development and dissemination of the Gospel over time. Because the 'other' was perceived as ignorant, the locals were suspicious of those that wielded the word.

Thirdly, the missionaries came with the implementation of a 'false dependence syndrome'. The fallacy was that the locals needed to depend on the missionaries and the West for survival. This cultivated a spirit that 'they cannot do without me'. According to Newbigin, Visser't Hooft and Niles (1960:41), there is a false dependence, which is the mark of infantility, of arrested development, while true dependency embraces all the parties. All parties see themselves as one family and each complements the other, each part has not only something to contribute but also much to receive. Once the basic responsibility to God is established, there is then a whole multitude of ways in which mutual dependence expresses itself in a living church. However, that was not the case with the missionaries, because the mission was limited to the doorstep on which the church was established not to expand to other areas. Other areas have to depend on the so-called mother-church for survival and such dependency crippled and compromised the spread of the Gospel or the good intentions of the missionaries. Consequently, the disadvantaged congregation felt aggrieved and started to have doubts about the purpose of the mission and its intentions. Drawing from the above context, the question is whether the Gospel as brought by the missionaries addressed the context of the indigenous people.

\section{Contests}

Despite the above constellations which expressed the negative sides of the missionaries, there were positive sides to that. Not all missionaries saw their invitation by the kings as an opportunity to establish mission stations as a priority and conversion of heathens. Others like Eugène Casalis and Thomas Arbousset went to Lesotho on the invitation of King Moshoeshoe. On arrival in Lesotho, their focus was on a mission through translation. Through translation, they were able to accomplish their church planting mission in Lesotho. From this endeavour, the study assumes that Casalis and Arbousset aligned themselves to Sanneh's (1989) book entitled Translating the Message, which has the following extract: 'vernacular translation often converged with steps to encourage indigenous ascendancy. In their vernacular work, Christian missions helped nurse the sentiments for national cause, which mother tongues crystallized and incited' (Sanneh 1989:125).

The above meant vernacular translation was a way of accommodating the Basotho indigenous people, and the acceptability of Christianity was easy and not imposed by the missionaries. That is why their first objective was to learn the indigenous language. Thereafter, they were in the position to translate the Bible into the vernacular. Translation of the Bible to the indigenous language and then learning the Bible in the mother tongue, the message was understood and read. The marginalisation of culture and inferiority complex was eliminated among the indigenous people, and the message was a receptacle to the indigenous.

The same could be said about Mozambique according to Vilanculos (2013) on how the contribution of the Protestant churches towards the independence of Mozambique has many different aspects. Vilanculos asserted that, primarily, the influence and contribution from these churches were seen through the introduction of mission schools in the 19th century in Inhambane (Cambine Mission), Lourenço Marques (Khovo Lar Secondary School and St Cipriano) and Gaza (Chicumbane and Maciene Missions). They encouraged literacy among the local people. For instance, these churches were the first to start ministering and teaching the population in vernacular languages and culture. They also encouraged Mozambicans to think about their own culture (anthropology), and this was very significant because Mozambicans were rehabilitating their own personality, self-esteem and selfrespect as well as their own dignity. Some distinguished figures in the history of Frelimo were trained in mission schools such as Eduardo Chivambo Mondlane, the first president of Mozambique, who was trained first in a Swiss Mission, currently called the Presbyterian Church School in Lourenço Marques - Maputo, then he studied agriculture at Cambine Mission. Graça Simbine and Daniel Mbanze were educated at Cambine Mission of Methodist Episcopal Church. Later on, Graça went to Chicuque Mission of the same church. Besides that, different Protestant churches were able to offer scholarships to African students to pursue higher education in Mozambique and others were sent overseas. This situation motivated Mozambicans to think deeply about the necessity and importance of independence.

In South Africa, the missionaries contributed towards the development of the Africans; Christianity, as a book religion and as an institution concerned with the moral life of the black people, has made a significant contribution in the genesis and continued development of formal Western education in sub-Saharan Africa and South Africa. In his research article, Daun (2000:37) writes: 'It is shown that religious factors count as much as (and sometimes more than) economic factors, first in the quantitative expansion of education and then in the decline'. In order for Christianity to make significant progress in its evangelisation activities, African people's literacy and numeracy had to improve drastically. This requirement necessitated serious education initiatives on the part of Christian missionaries. Hence, the establishment of learning institutions like Lovedale and Tiger-kloof just to mention the few, who were administered by the missionaries. The Protestant churches, in particular, were advocates of mass education, because of their emphasis on the need for all believers to read the Bible in his or her own language. 
However, from the above, it can be concluded that not all missionaries had the illusion of 'converting heathens' and bringing them to God. Others saw that as an opportunity to promote their imperialistic intention, while others like Casalis and Arbousset saw it as an opportunity that God's mission as mentioned in the Great Commission (Matt 28: 18-20) should be accomplished. This translation of the message embraces culture and worldview and church planting becomes easy. (This will be explained in the conclusion of the research.)

From the convictions of Newbigin discussed in the background context, the research assumes that mission, as conducted by the missionaries, failed to contribute positively to the societies and that led to doubt and suspicion about their intended purpose. However, there were instances where they contributed positively to the welfare of the communities they laboured. The research looks at what were causes of the above and what some missionaries failed to recognise. The research takes a specific focus on an African perspective.

\section{Mission not conducted from an African 'missiology'}

The mission of missionaries was based on the 'saving of souls' and 'evangelising the heathens' who were ignorant of the Gospel and needed to be transformed and converted (Witt 2012:19). The behaviour of the indigenous people, like in Africa, was interpreted from the missionaries' perspectives. Thence, the mission was a task for the missionaries and as such has to be seen from their own understanding. The fact that the Africans had a faith in their own understanding about God and religion was ignored. And their values were marginalised (Healy 1981:25; Mafico 2011:57; Mbiti 1990:3; Oladipo 2010:45). This perspective from various scholars clearly illustrated what one could term a theology of Africans' that was totally taken for granted. Their learnings and teachings that were transmitted orally from generation to generation and that had sustained them over time were not seen as an effective tool for this new missiology.

\section{Worldview and culture}

Owing to the perceptions that were prevalent among some missionaries, the consideration of the aborigine's worldview and culture was ignored in toto. From Africa, some missionaries failed to realise that faith was a 'rooted' principle among Africans. They ignored seeing that God of an African was related to the 'aborigines' surroundings and was part of their worldview and culture (Van der Leest 2012:27). God was also associated with the earth because according to this African worldview and culture humanity is part of the earth, explaining why the umbilical cord after the birth of the child is planted back into the earth to consolidate that deep relationship (Verstraelen 1996:95).

Ignoring the principles as outlined above which are anchored in African religious philosophy impacted negatively on the processes of transformation and conversion in Africa. It also failed to contribute to societies in conceptualising and accepting the Gospel. The result thereof was suspicion and doubt among Africans? The Gospel was seen as a Western imposition which aimed at colonising the mind of the indigenous African (Oladipo 2010:33).

\section{Mission and the church}

Owing to previous misconceptions, as already alluded to above, there exists doubt and mistrust in the church. For the success of the unity and contextualisation in the church, there is a need for an alternative model which is purposeful in restoring what God intended for his people. The alternative model should be severed from colonialism and a superior attitude which has thus far been displayed by colonialism. Colonialism was forceful in bringing people to God through repentance and obedience by inculcating passive and submissive means as a response to God's salvation. The missionaries made sure that indigenous people were indoctrinated and that the colonised are seen as non-equals in the eyes of God. Thence, the alternative model should be a church which is Trinitarian orientated and missionary in character, as described by Newbigin (Man-hei 2013:119) as a church, Christian as witnesses is pleasing to the Lord and will be characterised by irreducible plurality. It will be a manifold witness. The church is unity in diversity. Embracing the plurality of truths does not mean anything goes, but guards against triumphalistic attempts to exclude the voices of others. The complexity of the world does not exhaust the promise of God for the world.

The model of the church as described by Man-hei (2013) is complemented by Sarisky (2014:267), who contends that if Christians can count on the state to compel its citizens to convert, mission work needs to happen only outside the borders of Christendom. Missions would then be one thing the church does, along with numerous other things. In the post-Christian West, and in the wider world, this simply will not do. It would have been difficult for Newbigin to stress the centripetal aspect of the mission, while at the same time calling for the church to assume a post-Christendom stance in a different cultural situation. Newbigin's Trinitarian reconception of the church as the church in the mission was designed to motivate Christians in an unfamiliar, challenging context. The mandate he gave to the church is its as yet unfinished agenda.

From the conversation, it is evident that Newbigin's church was the church that would bring people together and promote unity. The church in unity is the one that brings people together as a close-knit family. The church in unity is based on missio Dei and its precepts. This church, in fostering unity, has met challenges that hinder the church to cross the frontiers of its mission. Besides the unity as advocated by scholars like Newbigin, the postmodern church is in turmoil because of the conflicts from within. This church is facing discrimination within itself and the contextual community. In itself, the church is not doing anything about segregation 
and discrimination of women: it has wrestled with how to address the problem. But that tends to be very problematic because of patriarchy and the culture that the present church has adopted relative to the past practices of the same church (see Marumo 2017:6).

Marumo (2017:18) alluded to the events that have negatively affected the unity in diversity purpose of the church and led to the church being seen as the opposite of missio Dei especially in the MCSA (Methodist Church of Southern Africa). The church is seen as a mockery of itself with the dire status of intended unity. The infighting among communities has thwarted the mission and led to humanity being despised by those who do not relate to the kingdom of God (Marumo in press). Marumo (in press) mentioned an example of the fight between the Shembe brothers in the Nazarene Church, which ultimately ended to be decided by the Supreme Court. This has impacted badly on how one understands that humanity is made in the image of God. The pertinent query is why people made in the image of God could be so disunited.

The above deliberations influenced the research to reach a conclusion that Newbigin's contributions to contextualisation and culture when blended could contribute positively to repairing the damage that colonialisation has done. This is possible if the mission of God is driven by the church which is Trinitarian in nature and that longs for unity. This unity must be seen as a unifying factor that brings forth the advocacy of humanity being made in the image of God. Cognisance should be taken that in the midst of oneness or koinonia the plant of mission needs to be irrigated so that it must be nurtured in the process of glorifying God. Thence, it would be imperative that evangelisation of the God's people should take place and the Good News should be the fertiliser that enhances their faith and brings shalom in the world wherein all humanity lives in harmony. This should be the springboard for spreading the Good News.

In confirming this, Newbigin (1982) suggested that:

It is only in the light of our experience of the grace of God in Christ that we know the terrible abyss of darkness into which we must fall if we put our trust anywhere but in that grace. (p. 151)

\section{Contextualisation and mission}

Contextualisation, according to Hewitt (2012:14 in Marumo 2013:83), is a process in which psychological and social functions of communities are expressed through communication. In this communication, people come together around a given piece of information and exchange ideas, attitudes, values and feelings. Theologically, it means that contextualisation is a pastoral method that studies the particular koinonial context in which events unfold and bring forth meaning. There are three types of contextualisation, namely translational, dialectical and liberational. All these types seek to integrate the Gospel message with local culture in such a way that the message becomes a part of the cultural system itself, which is applicable to koinonia and serves as a breeding ground for unity. Because where there is koinonia, there is shalom, and where there is shalom, God is glorified.

There is a need for a missiological paradigm based on contextualisation that could empower missionaries to contribute positively towards conversion and transformation of societies. This paradigm should be embedded in missio Dei. Cognisance should be taken that there were missionaries who contributed positively towards transformation and conversion in Africa; for example, missionaries like Eugène Casalis and Thomas Arbousset translated the Bible into an indigenous language in Lesotho (Sanneh 1989:125).

The other contention by religious scholars is that Christianity was not a new phenomenon in Africa. For example, there are scholars who maintain that before the missionaries embarked on what was termed the 'partition of Africa', Africans were religiously inclined towards Christianity which was embedded in their worldview. Parrinder (1969:101), Hildebrandt (1981:101) in Ore (2010:148) argue that:

the entry of Christianity in Africa was during the Pentecost Day in AD 30 meaning in actual fact one could say that Christianity came to Africa before the institutionalized church; for Joseph of Arimathea who carried the cross of Jesus Christ was believed to be an African probably from modern day Turkey. This implies that even before the preaching of the day of Pentecost, Africans had the taste of the Gospel. (p. 148)

The prior knowledge of Christianity as mentioned above is a clear indication that Africans in themselves acknowledge the existence of God. What is important to note is how Africans came to contextualise God in their worldview and culturally. The understanding thereof plays a pivotal role in underpinning the Christianity perspective and gives meaning to missiological agenda in a postcolonial era as envisioned by Newbigin.

\section{Missiological agenda as envisioned by Newbigin}

So the research has articulated around the challenges and opportunities that the church is facing. But in a postmodern era where the church is segmented by globalisation, technology and marginalisation, and populism, it is imperative that the following should be taken into account.

Firstly, Mashoko (2005:79) argues that the ushering of the postcolonial era saw the demise of contextualisation and that was the challenge that the church needed to address as a matter of urgency. It was urgent because if not being done it was going to nullify what Goheen (2000:3) draws from Newbigin who contended that the Gospel or any Biblical scripture should be presented in the way that the hearers will understand; this means that the worldview and the cultural background of the hearers play an important role in evangelising. Preferably, as Newbigin maintains, the language of the hearers should be used or the services of a good interpreter should be utilised. If these are not in place, the message will be distorted and lose its meaning and context. 
Newbigin adds that language barriers should be avoided at all cost; if the missionary cannot get an interpreter then he or she must live in that community, learn their language and culture, or enrol in an education centre to be taught the language. In that way, the language problem will be addressed and the worldview and culture would have been learned.

Secondly, it is clear from Newbigin's notion that worldview and culture played a prominent role in spreading mission in a postcolonial era. Another important thing was the dismantling of language barriers to allow the hearers to interpret the Gospel from their own understanding and reflect that in their everyday lives. From the research point of view, it was going to be harmful to the hearers to accept without understanding and to accept without comprehending that in their everyday lives. Gospel calls for faith and faith cannot be acceptable when it does not address my immediate surroundings and can reflect my worldview and culture. Thence, Newbigin was correct to call for contextualisation and to encourage that language as a means of communication should be a medium that can assist the church in its mission.

Thirdly, another challenge that is imminent in mission, according to Macleod (2014:212), was the taking over of the education from the missionaries by the government. What followed was the compromise that the taking over or the annexation by government thwarted away the mission of the church which was based on growth. The growth was based on inculcating norms and morals that made people see each other as human beings. But that was not achieved because as we entered the 21st century, the church was reduced to be secularised in character and that impeded growth as well as Christianity. Globalisation took over and reliance on modern technology played a major role in exposing people to modern science and education. In essence that resulted in people relying more on themselves as reasoning took over. The postcolonial era was a hive for moral decay and decline of membership.

Fourthly, globalisation came in with intents and purposes, but it did not change the human character. However, humanity became a victim of globalisation because it influenced the character and culture and that resulted in moral degeneration. When moral degeneration is prevalent in a community, that community loses its integrity and it affects growth. Globalisation changes the mindset of humanity and the seed of reasoning found a fertile ground to germinate; moreover, there exists doubt because of the fact that the Gospel was seen as not addressing the attributes of the community and it was contextualised.

Besides the above challenges, the research argues that there exist opportunities that when exploited can bring the meaning of mission and unity to the church. Preachers should be given training in the understanding of the Gospel. Development of laity should be given a priority. It will be worthwhile for the church to spend more resources in human capital so that contextualisation can be realised. This is what
Newbigin meant when he expounded on breaking away from the barriers. The church should cross the frontiers and be proactive. In its proactiveness, it should take people first, taking cognisance that the mission belongs to God and church is the instrument of missio Dei. The church should start a contextualisation process among its leaders and preachers.

From the above notion, transformation and conversion could be possible because there are traces and marks of transformation and conversion. The Gospel is therefore not new: Africans believe in a 'Supreme Being' who was called by different names in relation to their own experiences. Taking that as a launch pad for transformation and conversion, the missionaries in a postcolonial era embarked on what this research terms contextualisation in the process: 'working from the known to the unknown'. The 'preunderstanding' with which the contemporary community comes to its reading of the Bible is shaped by the ways in which previous generations of Christians have come to understand it in the course of discipleship. Each Christian reader comes to the Bible with the spectacles provided by the tradition that is alive in the community to which he or she belongs (Newbigin 1986:56).

Drawing from the above context, the missionaries should take recognition of the Christian potential which Africans have and from there contextualise it with the missional Gospel. That brings a new dimension to an understanding of the Gospel and transformation and conversion. Taking the worldview and the cultural settings of the indigenous people and cultivating potential invariably gives them dignity and restores them from the marginalised territory into which they were categorised. Furthermore, such recognition would remove suspicion and doubt and give rise to a united society in search of God.

From thereon, both parties should embrace and appreciate each other's contributions. The undermining of indigenous people's worldviews and cultures causes resistance and hinders progress. So for transformation and conversion to be attained, both worldviews and cultures should be respected, where there is not a superior worldview and a superior culture.

\section{Newbigin (1986) mentions that:}

the exponents of sociology have made us familiar with the fact that our sense of what is real is, to a large extent, a function of the society in which we live in. It is almost impossible for an individual to deny steadily the reality of things that society regards as real, or to affirm the reality of things that society regards as illusions. The plausibility structures that largely control our perceptions of what is the case is socially produced. (p. 54)

That is why it is imperative that mission and the church should intertwine, and in that marriage they should take cognisance of each other and embrace each other's worldview. For the success of the marriage, it is imperative that each 
should be a full partner of the union and that is only possible when partners are equal. The pillar of equality must be contextualisation. The church is there as a tool for missio Dei; thence, it should not undermine other people but live in harmony with them as God's children and promote unity in diversity.

The researcher reiterates contextualisation is the answer to the mission in the postcolonial era. In that, another important factor which could assist the church in the postcolonial era is to realise that all that it deals with is humanity. And humanity desires to live in unity because of the image of God embedded in them even though there could be others who instigate division, but the majority wants to live in koinonia with each other. That element is paramount and can serve as an opportunity that the church can exploit to achieve the mission. The church needs to preach the Gospel of the Cross without being apologetic and showcase that humanity cannot save themselves; ONLY God can save humanity. In its endeavours, they must move with the community, they must not leave it behind, meaning through contextualisation of the message the community will have a better understanding and that will assist reflection of the message to themselves.

\section{Conclusion}

The church has a mandate to (Matt 28):

go and make disciples of all nations, baptizing them in the name of the Father and of the Son and of the Holy Spirit, and teaching them to obey everything.... (vv. 18-19)

Holistic community development is part of God's agenda, and the church stands a chance to accelerate the transformation of people's lives for the better. Understanding the stance of the church of East Africa today in light of its inception unveils gaps created during the precolonial and nurtured through the postcolonial era. For the church to strategically address these gaps, stakeholders need to unite and forge the way forward as a unified army. Overcoming denominational, ethnic and geographical barriers will synergise the church to accelerate holistic development to God's glory (Mbogo 2015:175).

Missio Dei as God's plan cannot work in isolation and is there to fulfil God's mission on earth. It is involved in the whole creation working towards shalom. The church's mission is flowing forth from God and is partaking in the missio Dei in the realisation of shalom and unity. Therefore, sending out messengers on a mission and giving them authority and mandate to baptise them in the name of the Father, Son and Holy Spirit is the force that drives the church to cross boundaries. Crossing boundaries or barriers is not selective; it embraces all despite geography, culture, ideology, social class, language and race to bring shalom, koinonia in the promotion of unity. Baptising is for all nations.

As the research concludes, it maintains that the church should cross the barriers because that leads to the formulation of the definition of mission. The church mission flows from the realisation that mission is first and foremost God's mission (missio Dei) and that the church is called to a holistic witness which crosses boundaries. The church is called to participate in God's work through different ministries (functions or obligations). Its participation should include people with different culture, language, creed, sex and nationality. When that is done, the postcolonial church will serve the missio Dei and God will be glorified.

\section{Acknowledgements Competing interests}

The author declares that he has no financial or personal relationships that may have inappropriately influenced him in writing this article.

\section{Funding information}

The publication of this study was funded by North-West University.

\section{References}

Daun, H., 2000, 'Primary education in sub-Saharan Africa - A moral issue, an economic matter or both?', Comparative Education 4(1), 37-53. https://doi.org/10.1080/ 03050060027755

Goheen, M., 2000, Gospel and cultures: Newbigin's missionary contribution, viewed 20 February 2018, from http://www.gospelcom.net/re/index.html

Healy, J.G., 1981, A fifth Gospel: The experience of black Christian values, Maryknoll, Orbis Books, New York.

Hewitt, R.R., 2012, Church and culture: An Anglo-Caribbean experience of hybridity and contradiction, Cluster Publications, Pietermaritzburg.

Hildebrandt, J., 1981, History of the Church in Africa, Christian Press, Achimota.

Lyall, L.T. \& Newbigin, L., 1962, The Church local and universal, The World Dominion Press, London.

Macleod, A.M., 2014, 'Open Church: Interpreting Lesslie Newbigin's missiology in India today', PhD dissertation, Faculty of Theology (Missiology), University of South Africa.

Mafico, T.L.J., 2011, 'The land and the African context of theology', Journal of the Interdenominational Theological Center 37(1-2), 68.

Man-hei, Y., 2013, 'Truth in a pluralistic world. A dialogue with Lesslie Newbigin', Currents and Mission 40(2), 112-119.

Marumo, P.O., 2013, 'A dialogue between African philosophy and missio Dei: Koinonia and ubuntu', Masters dissertation, Faculty of Theology (Missiology), North-West University.

Marumo, P.O., 2017, 'A call for the recognition and empowerment of women in ministry in the Methodist Church of Southern Africa', Studia Historiae Ecclesiasticae 42(6), 6-21.

Marumo, P.O., (in press), 'Reconciliation in South Africa in light of the Imago Dei and Koinonia', Verbum et Ecclesia.

Mashoko, F., 2005, 'The need for the contextualization in inter-cultural communication of the Gospel', Masters thesis, Faculty of Theology (Missiology), University of South Africa.

Mbiti, J.S., 1990, African religions and philosophy, 2nd edn., Heinemann Educational Books Inc., London.

Mbogo, R.M., 2015, 'Historical factors for the Church involvement in holistic community development in East Africa', Developing Country Studies 5(21), 169-176.

Newbigin, L., 1961, A faith for this one world, SCM Press Ltd, London.

Newbigin, L., 1982, 'Crosscurrents in ecumenical and evangelical understanding of Missio', International Bulletin of Missionary Research 6, 146-151.

Newbigin, L., 1986, Foolishness to the Greeks: The Gospel and western culture, SPCK, Eerdmans Publishing Company, Grand Rapids.

Newbigin, L., Visser't Hooft, W.A. \& Niles, D.T., 1960, A decisive hour for the Christian mission, SCM Press Ltd, London.

Oladipo, C., 2010, 'African Christendom in the twenty first century', Ogbomoso Journal of Theology 15(2), 33-71.

Ore, R.O., 2010, 'Paradigm shift in mission from biblical perspectives', Ogbomoso Journal of Theology 15, 147-157. 
Sanneh, L., 1989, Translating the message: The missionary impact on culture, Maryknoll, Orbis Books, New York.

Sarisky, D., 2014, 'The meaning of the missio Dei: Reflections on Lesslie Newbigin's proposal that mission is of essence of the church', An International Review 42(3), 257-270. https://doi.org/10.1177/0091829613497465

Van der Leest, S.H., 2012, 'Engineering is not science', Perspective on Science and Christian Faith (64)13, 20-30.
Verstraelen, F.J., 1996, 'Land, development and ecology: Missio-theological reflection from the Pacific and Africa', Missions Studies 13(1-2), 189-206. https://doi. org/10.1163/157338396X00104

Vilanculos, J.A., 2013, 'The role played by Church and State in democratisation process in Mozambique, 1975-2004', viewed 23 May 2018, from www.scielo.org.za/pdf/ she/v39n2/19.pd

Witt, T., 2012, 'Singing with the Earth and the Global Church', Liturgy 27(2), 17-30. https://doi.org/10.1080/0458063X.2012.638787 